\title{
SYNTHESIS AND COFORMATIONAL BEHAVIOR OF SULFINYL- OR SULFONYL-BRIDGE CONTAINING p-tert-BUTYLCALDX[4]ARENES
}

\author{
Daisuke Watanabe, Toshio Ito, Kazuaki Ito, and Yoshihiro Ohba* \\ Department of Chemistry and Chemical Engineering, Faculty of Engineering, \\ Yamagata University, Yonezawa 992-8510, Japan
}

\begin{abstract}
Calix[4]arene derivatives incorporating the sulfinyl or sulfonyl moiety as a bridge were synthesized by the oxidation of the monothiacalix[4]arene precursors. Conformational analysis of a novel monosulfinylcalix[4]arene and monosulfonylcalix[4]arenes using NMR spectroscopy in $\mathrm{CDCl}_{3}$ solution is presented
\end{abstract}

There is current interest in the development of new types of host compound "Calixarenes" as a family of macrocyclic oligophenols.' Many studies have been done on the modification of the lower and/or upper rims of the calixarenes. ${ }^{2}$ However, there are only few studies to replace the bridging methylene groups by $\mathrm{S}$. We first reported the synthesis and inclusion properties of the p-lert-butylthiacalix[4]arene (TC4A) in which four bridging $\mathrm{CH}_{2}$ groups are replaced by $\mathrm{S}^{3}$ Since Miyano et al. first reported the facile one-step synthesis of TC4A, many studies dealing with TC4A have been published. ${ }^{\text {sh }}$ so The X-ray crystal structures of TC4A ${ }^{6}$ and the complexation properties with metal ions by $T C 4 A^{7}$ have been reported. Very recently, the synthesis of the sulfinyl- and sulfonylcalix[4]arenes and their coordination ability to metal ions were reported by Miyano et al. ${ }^{2}$ and the $\mathrm{X}$-ray structures of the tetrasulfinylcalix[4]arenes and tetrasulonylcalix[4]arenes have been reported by Hosseini et al. ${ }^{9}$ The letter results gave us only information about the crystal structure of the thiacalix[4]arenes. We could not obtain direct

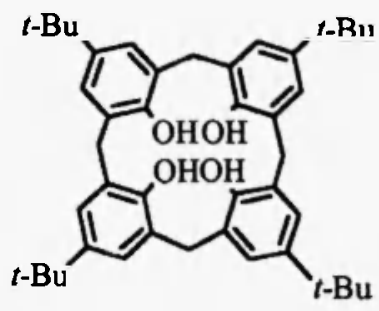

1<smiles>Cc1cc(C)c(O)c(Cc2cc(C)cc(Cc3cc(C)cc(C)c3O)c2O)c1</smiles>

$\mathbf{5}$

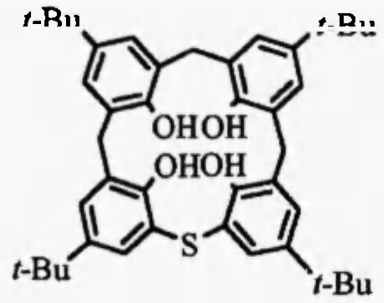

2

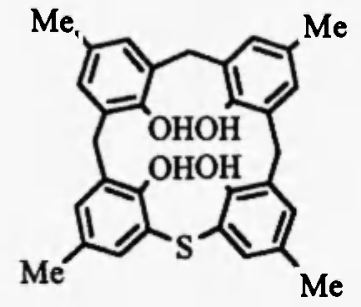

6

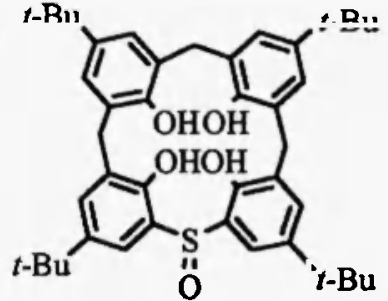

3

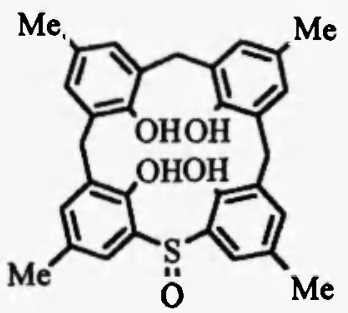

7

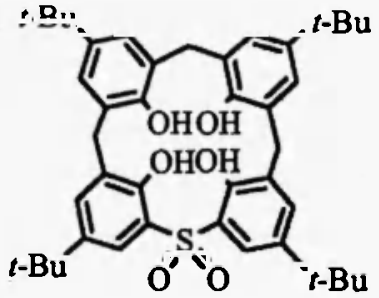

4

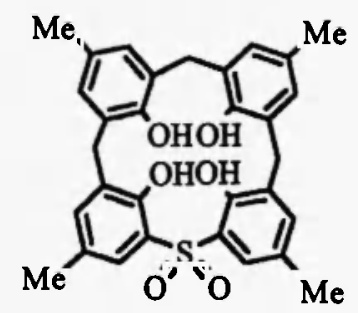

8 
information concerning the dynamic inversion behavior of the phenol connected to the sulfenyl bridge, because all of four methylene bridges were replaced by sulfenyl- or sulfinyl- or sulfone-bridges. Precise information of the dynamic behavior of the phenol units is important for the design of calixarenes as synthetic receptors. This strongly prompted us to investigate the effect of the sulfenyl- and sulfinyl- and sulfonyl-bridge of the calixarene on their dynamic behavior in solution.

The calixarenes 3, 4, 7 and 8 were synthesized by the selective oxidation of the corresponding calix[4]arenes ${ }^{3}$ using $m$ chloroperbenzoic acid ( $m$-CPBA) in $39-57 \%$ yield (Scheme 1). In a typical run, to a solution of $2(100 \mathrm{mg}, 0.15 \mathrm{mmol})$ in chloroform ( $10 \mathrm{ml})$ was added $m$-CPBA $(26 \mathrm{mg}, 0.15 \mathrm{mmol})$ in chloroform $(5 \mathrm{ml})$ at $0.5{ }^{\circ} \mathrm{C}$ over a period of $1.5 \mathrm{hr}$. After the mixture had been stirred for $1 \mathrm{hr}$ at room temperature, the reaction mixture was washed with saturated sodium hydrogen sulfite, saturated sodium hydrogen carbonate and then with water. After the chloroform was removed, the residue was recrystallized with acetonitrile to give 3 ( $40 \mathrm{mg}, 39 \%$ ). When compound 3 was treated with sodium carbonate, the sodium phenoxide compound $\left(3^{-}+\mathrm{Na}^{+}\right)$was formed (Scheme 2). This means that the introduction of a sulfinyl group as the bridging joint of the phenols increased the acidity of one neighbor phenol which released a proton to form the phenoxide. The ' $\mathrm{H}$ NMR spectrum of this salt shows $3 \mathrm{H}$ phenolic protons. The mass and elemental analysis also proved the formation of this salt. The obtained new macrocyclic compounds were identified on the basis of IR, mass, ID and 2D NMR spectral data and elemental analyses. ${ }^{10}$

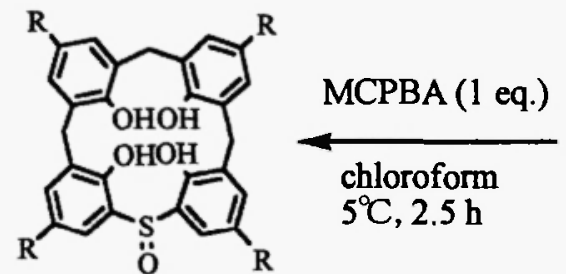

3: $\mathrm{R}=t-\mathrm{Bu}$
$\mathrm{R}=\mathrm{Me}$<smiles>[R]c1cc([R])cc(Cc2cc([R])cc(-c3cc([R])cc(Cc4cc([R])cc(Sc5cc([R])cc(O)c5O)c4O)c3)c2O)c1</smiles>

2: $\mathrm{R}=t-\mathrm{Bu}$ 6: $\mathrm{R}=\mathrm{Me}$

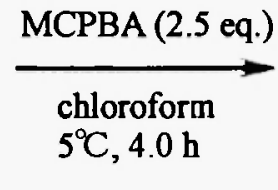<smiles>[R]c1cc(O)c(O)c(Cc2cc([R])cc(Cc3cc([R])cc(S(=O)(=O)c4cc([R])cc([R])c4O)c3O)c2O)c1</smiles>

4: $\mathrm{R}=t-\mathrm{Bu}$

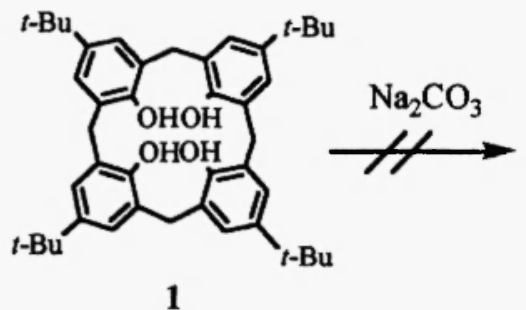

1<smiles>CC(C)(C)c1cc(Cc2cc(C(C)(C)C)cc(Cc3cc(C(C)(C)C)cc(S(=O)c4cc(C(C)(C)C)cc(C(C)(C)O)c4O)c3O)c2O)cc(C(C)(C)C)c1</smiles>

3<smiles>CC(C)(C)c1cc(Cc2cc(C(C)(C)C)cc(Cc3cc(C(C)(C)C)cc(Cc4cc(C(C)(C)C)cc(C(C)(C)O)c4O)c3O)c2O)cc(C(C)(C)C)c1</smiles>

$\mathrm{I}^{-}+\mathrm{Na}^{+}$

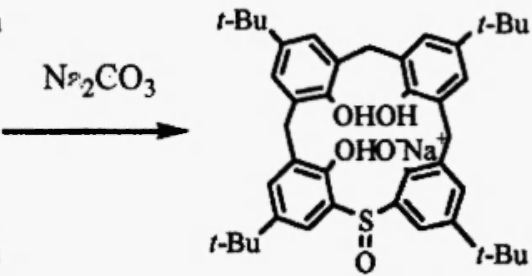

$3^{-}+\mathrm{Na}^{+}$

Scheme 2 
Table 1. Partial spectral data, energy barriers $\left(\triangle \mathrm{G}^{*}\right)$ of conformational inversion.

\begin{tabular}{|c|c|c|c|c|c|c|c|}
\hline Compd & $\begin{array}{l}\text { Temp. } \\
\text { (C) }\end{array}$ & $\begin{array}{l}\delta \mathrm{OH}^{*} \\
\left(\mathrm{~cm}^{1}\right)\end{array}$ & $\begin{array}{r}\delta \mathrm{OH} \\
(\mathrm{ppm})\end{array}$ & $\begin{array}{c}\delta \mathrm{ArCH}_{2} \mathrm{Ar} \\
(\mathrm{ppm})\end{array}$ & $\begin{array}{c}\delta \mathrm{CH}_{2}(\triangle \delta) \\
(\mathrm{ppm})\end{array}$ & $\begin{array}{l}T_{\mathrm{c}} \\
\left({ }^{\circ} \mathrm{C}\right) \\
\end{array}$ & $\begin{array}{c}\triangle \mathrm{G}^{*} \\
\left(\mathrm{kcalmol}^{1}\right)\end{array}$ \\
\hline 2 & $\begin{array}{l}+20 \\
-60\end{array}$ & 3170 & $\begin{array}{c}10.14 \\
10.37,10.06,10.02\end{array}$ & $32.7,32.9$ & $\begin{array}{l}4.26,3.54(0.72) \\
4.29,3.61(0.68) \\
4.27,3.58(0.69)\end{array}$ & 45 & 14.8 \\
\hline 3 & $\begin{array}{l}+20 \\
-60\end{array}$ & 3200 & $\begin{array}{c}9.70,9.86,10.99 \\
8.5-10.5(b r) \\
11.05\end{array}$ & $31.8,32.5$ & $\begin{array}{l}4.24,3.56(0.68) \\
4.25,3.62(0.85) \\
4.25,3.62(0.63) \\
4.25,3.61(0.64) \\
4.33,3.55(0.78)\end{array}$ & 55 & 14.8 \\
\hline $3^{-}+\mathrm{Na}^{+}$ & $\begin{array}{l}+20 \\
-60\end{array}$ & 3190 & $\begin{array}{c}12.8,13.7 \\
14.21 \\
13.39,12.78\end{array}$ & $33.2,33.6$ & $\begin{array}{l}4.26,3.46(0.79) \\
4.60,3.44(1.16) \\
4.24,3.48(0.76) \\
4.36,3.48(1.16)\end{array}$ & - & c \\
\hline 4 & $\begin{array}{l}+20 \\
-60\end{array}$ & 3300 & $\begin{array}{c}10.41,9.43 \\
10.93,10.24 \\
9.99,8.75\end{array}$ & $32.0,32.5$ & $\begin{array}{l}4.29,3.55(0.74) \\
4.24,3.58(0.66) \\
4.30,3.61(0.73)\end{array}$ & 37 & 14.0 \\
\hline 6 & $\begin{array}{l}+20 \\
-60\end{array}$ & 3200 & $\begin{array}{c}9.92 \\
10.24,10.14 \\
9.92,9.84\end{array}$ & $31.7,32.0$ & $\begin{array}{l}4.16,3.46(0.70) \\
4.12,3.24(0.88) \\
4.22,3.48(0.78)\end{array}$ & 36 & 14.1 \\
\hline 7 & $\begin{array}{l}+20 \\
-60\end{array}$ & 3200 & $\begin{array}{c}9.62 \\
10.90,9.90 \\
9.56\end{array}$ & $30.9,31.6$ & $\begin{array}{l}4.18,3.45(0.78) \\
4.19,3.45(0.73) \\
4.27,3.50(0.77)\end{array}$ & 46 & 14.4 \\
\hline 8 & $\begin{array}{l}+20 \\
-60\end{array}$ & 3230 & $\begin{array}{c}10.23,9.19 \\
10.63,9.98 \\
9.90,8.91\end{array}$ & $30.9,31.7$ & $\begin{array}{l}4.13,3.49(0.64) \\
4.18,3.52(0.66) \\
4.25,3.52(0.73)\end{array}$ & 34 & 13.9 \\
\hline
\end{tabular}

${ }^{\circ}$ inCHCl${ }_{3}{ }^{b} \mathrm{CDCl}_{3}$ at room temp. at $500 \mathrm{MHz}^{\mathrm{c}}$ no inversion even at $60^{\circ} \mathrm{C}$

The ${ }^{1} \mathrm{H}$ and ${ }^{13} \mathrm{C} \mathrm{NMR}$ spectra of $2,3,3+\mathrm{Na}^{+}, 4,6,7$ and 8 gave some interesting informations on the behavior of new type of monothiacalix[4]arenes (Table 1). The $\mathrm{ArCH}_{2} \mathrm{Ar}$ methylene protons of $2,3,3^{+}+\mathrm{Na}^{+}, 4,6,7$ and 8 appear as a pair of doublets due to geminal coupling between exo-H and endo- $\mathrm{H}$. According to the Gutsche rule ${ }^{11}$, the chemical shift difference ( $\triangle \delta$ ) between exo-H and endo-H in the calix[4]arenes is $0.9 \pm 0.2 \mathrm{ppm}$ for the cone conformation. The $\Delta \delta$ values of these calix[4]arene derivatives were $0.66-1.16 \mathrm{ppm}$. This rule is also applicable to this monothiacalix[4]arene system. Consequently, it follows that the adjacent aryl rings of these monosulfenyl-bridged calix[4]arenes take the preferably syn-orientation. The ${ }^{13} \mathrm{C}$ chemical shifts of the methylene carbon of the $\mathrm{ArCH}_{2} \mathrm{Ar}$ in monosulfinylcalix[4] arenes (3 and 7 ) exhibit two $\mathrm{CH}_{2}$ carbonsignals<smiles>[R]c1ccc(O)c(C(CCCCCC)c2ccccc2O)c1</smiles>

$\Delta \delta$ values $=0.9+0.2$

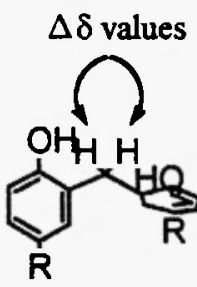

flattened cone<smiles>[R]c1ccc(O)c(C(c2ccccc2)c2ccccc2O)c1</smiles>

1, 3-alternate

$\Delta \delta$ values $=0.5+0.1 \quad \Delta \delta$ values $=0.0$

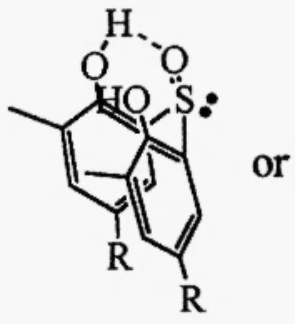

$S=0$ endo-confomer

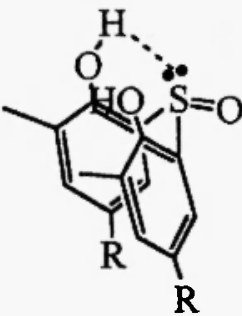

$S=0$ exo-confomer
Figure 1. Conformational dependence of the chemical shift $(\Delta \delta)$ between the high and low field pair of resonance of the methylene protons in the calix[4]arene
Figure 2. Schematic views of intra-hydrogen bonding 
at $\delta$ 30.7-33.6, indicating syn-oriented adjacent phenol rings in calix[4]arenes. ${ }^{12}$ The dynamic ${ }^{1} \mathrm{H}$ NMR spectra of the new calix[4]arenes were measured using chloroform- $d_{1}$ as the solvent. The analysis of the variable temperature ${ }^{1} H$ NMR spectra of 3 is shown in Fig. 1. This indicates that a conformational reversible equilibrium between the $S=0$ endo-conformer and the $S=0$ exa-conformer exists at ambient temperature (Fig. 2) and both the major and minor conformer were detected at $-20^{\circ} \mathrm{C}$ (Fig. 3). It is known that oxygen atom of sulfinyl group can form the very strong hydrogen bonding. ${ }^{13}$ Furthermore, it is found that the $\mathrm{S}=0$ endo-conformer is stabilized in solid state on the basis of the X-ray result reported by Hosseini et al ${ }^{10}$ As shown in Table 1, OH signals of 3 at room temperature were observed at the more low field ( $\delta 10.99$ ) due to the hydrogen bonding. We suggest that 3 takes the $\mathrm{S}=0$ endo-conformer as major-confomer in solution, but this should be considered as tentative. On the other hands, Figure 4 shows the expansion of the $\mathrm{OH}$ region of the monosulfonyl-containing calix[4]arene (4) of variable temperature ${ }^{1} \mathrm{H}$ NMR spectra. At $-60^{\circ} \mathrm{C}$, remarkably, four $\mathrm{OH}$ signals at $\delta 8.75,9.99,10.24$ and 10.93 in a $1: 1: 1: 1$ ratio were also observed., whereas two $\mathrm{OH}$ signals at $\delta 9.43$ and 10.41 in a $1: 1$ ratio were observed at room temperature. These results show that 4 has

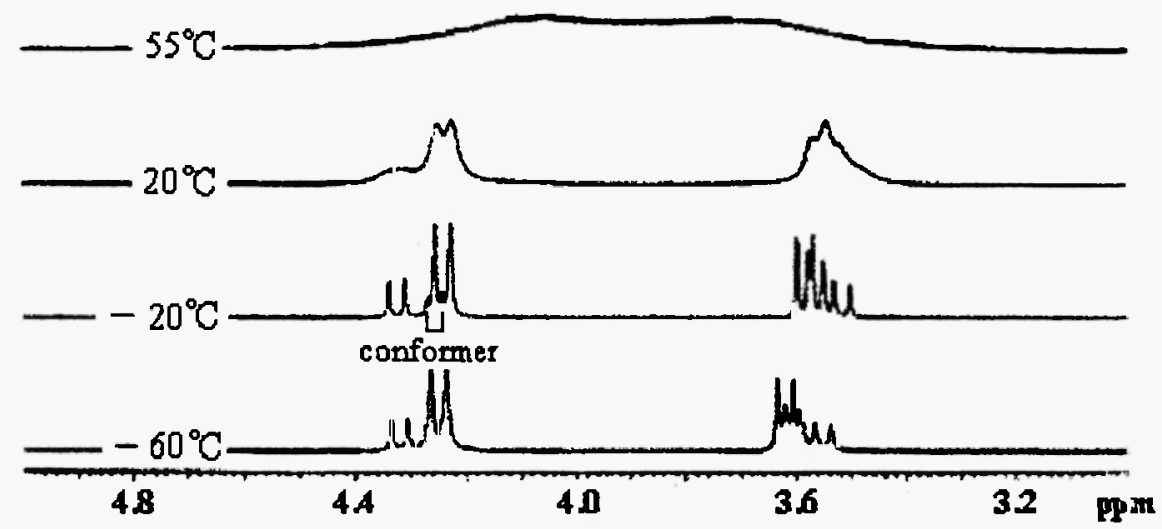

Figure 3. 'H NMR spectra of the 3 in $\mathrm{CDCl}_{3}$ at $500 \mathrm{MHz}$. (expansion of the methylene regions)

fixed hydrogen-bondings both clockwise and counter-clockwise at $-60^{\circ} \mathrm{C}$. Accordingly, it appears that the $\mathrm{OH}$ group of phenol adjacent to sufonyl bridge and another $\mathrm{OH}$ groups of phenol bridged methylene bridges form hydrogen bonds with sulfonyl group, or with a neighboring $\mathrm{OH}$, and rapidly exchange the $\mathrm{OH}$ protons at room temperature. This must be a very important finding that 4 has the possibility to exist in the irreversible racemic mixture at $-60^{\circ} \mathrm{C}$. (Scheme 3$){ }^{14}$ The coalescence temperature $\left(T_{c}\right)$ and the free energy barriers $\left(\Delta G^{\top}\right)$ for the conformational inversion of calix[4]arene analogues, which are calculated ${ }^{15}$ from the coalescence data, are shown in Table 1.

The sodium salt of the monosulfinyl-bridged calix $[4]$ arene $\left(3^{-}+\mathrm{Na}^{+}\right)$has the highest $\Delta G^{\ddagger}$ value $(>14.8 \mathrm{kcal} / \mathrm{mol})$ for the inversion of the diarylmethane units $\left(4<2,3<3^{-}+\mathrm{Na}^{+}\right)$. The order of the free energy barriers $\left(\Delta \mathrm{G}^{*}\right)$ for the conformational inversion are as follows: $\mathrm{SO}_{2}<\mathrm{S}=\mathrm{SO}$ for the tert-butylcalix[4]arenes. Contrary to this, the result of the $p$-methylcalix[4]arene derivatives (6-8) showed a difference in the $\Delta \mathrm{G}^{\ddagger}$ values $(8<6<7)\left(\mathrm{SO}_{2}<\mathrm{S}<\mathrm{SO}\right)$. These findings imply that the degree of efficiency toward the phenol inversion caused by the hydrogen bonding between $\mathrm{SO}$ and $\mathrm{OH}$ and that of $\mathrm{SO}_{2}$ and $\mathrm{OH}$ are entirely different. The sulfinyl-group had an increased $\Delta G^{\ddagger}$ for the conformational inversion, but the sulfonyl group had a decreased one. Contrary to the NMR spectral results, the IR spectra of these new calix[4]arenes in $\mathrm{CHCl}_{3}$ display the following sequence: the $\mathrm{OH}$ stretching bands of the phenol $\mathrm{OH}$ were observed in the $3170-3300 \mathrm{~cm}^{-1}$ region and showed the sequence $2<3<4$. These IR spectral data show that the circular hydrogen-bonding characteristic of the calixarenes is weakened by strong intramolecular 

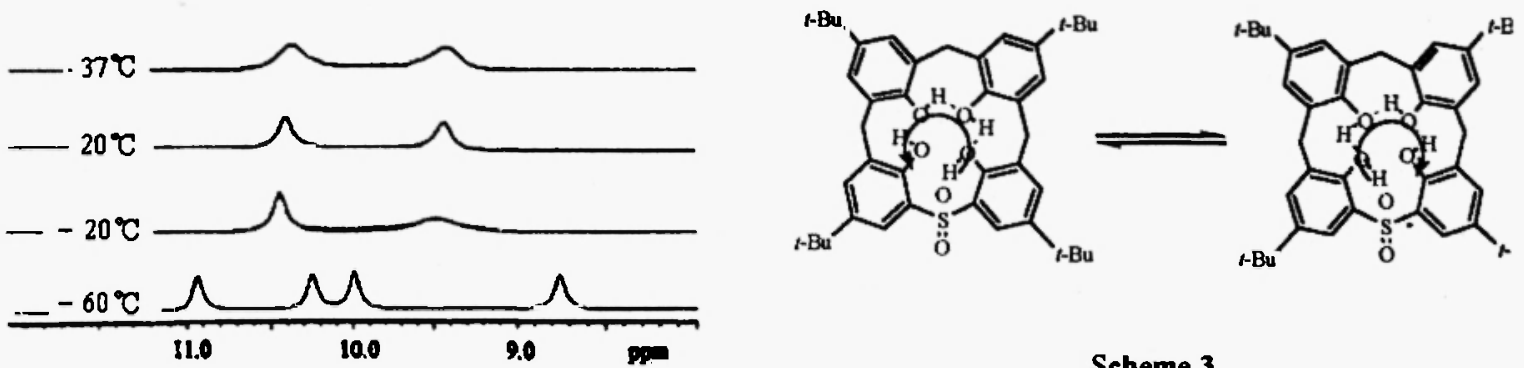

Scheme 3

Figure 4. ${ }^{\mathrm{H}} \mathrm{H} \mathrm{NMR}$ spectra of the 4 in $\mathrm{CDCl}_{3}$ at $500 \mathrm{MHz}$ (expansion of the $\mathrm{OH}$ regions)

hydrogen bonding between the phenolic $\mathrm{OH}$ and bridging $\mathrm{SO}$ and $\mathrm{SO}_{2}$ group in the calixarenes. ${ }^{16}$ Other steric factor to increase $\Delta G^{*}$ values of 3 and 7 should also exist. But there is no reasonable idea to explain the highest $\Delta G^{*}$ values of 3 and 7 .

In conclusion, we have shown the synthesis of the monosulfinyl- and monosulfonyl-bridged calix[4]arenes and the study of their dynamic behavior in solution using the NMR spectroscopy. The ${ }^{1} \mathrm{H}$ and ${ }^{13} \mathrm{C} N \mathrm{NR}$ spectra indicated that these new calix[4]arenes have a cone conformation. The introduction of the sulfinyl group as a bridging moiety of the phenols in the calix[4]arene derivative caused the increase in the $\Delta G^{*}$ values concerning inversion of the diarylmethane units. On the other hand, the sulfonyl-group decreased that in the order $\left(4<2,3<3^{-}+\mathrm{Na}^{+}\right)$.

\section{References and Notes}

1. C. D. Gutsche, "Calixarenes", Monographs in Supramolecular Chemistry, Ed. J. F. Stoddart, R. S. C. London, 1989; "Calixarenes - $A$ Versatile Class of Macrocyclic Compounds" Eds. J. Vicens, V. Bohmer, Kluwer, Dordrecht.

2. S. Shinkai, in Advances in Supramolecular Chemistry, 3, pp. 97-130, Gokel G. W. Ed. JAI. Press Inc. Ltd., London, 1993; V. Bohmer, Angew. Chem. Int. Ed Engl. 34, 713 (1995).

3. T. Sone, Y. Ohba, K. Moriya, and H. Kumada, H. Book of Abstracts for Workshop on Calixarenes and Related Compounds, p. PS/B-36, 2-4 June, 1993, Fukuoka, Japan, T. Sone, Y. Ohba, K. Moriya, H. Kumada, and Ito K. Tetrahedron, 53, 10689 (1997)

4. H. Kumagai, M. Hasegawa, S. Miyanari, Y. Sugawa, Y. Sato, T. Hori, S. Ueda, H. Kamiyama, and S. Miyano, Tetrahedron Lett., 38, 3971 (1997).

5. a) G. Mislin, E. Graf, M. W. Hosseini, A. De Cian, and J. Fischer, J. Chem. Soc. Chem. Commun., 1345 (1998). b) J. Lang, H. Dvorakova, I. Bartosova, P. Lhotak, I. Stibor, and R. Hrabal, Tetrahedron Lett., 40, 373 (1999).

6. N. Morohashi, N. Iki, C. Kabuto, and S. Miyano, Tetrahedron Lett., 41, 2933 (2000); G. Mislin, E. Graf, M. W. Hosseini, A. De Cian, and J. Fischer, Tetrahedron Lett., 40, 1129 (1999).

7. P. Lhotak, M. Himl, S. Pakhomova, and I. Stibor, Tetrahedron Lett., 39, 8915 (1998); M. Narita, Y. Higuchi, F. Hamada, and H. Kumagai, Tetrahedron Lett., 39, 8687 (1998); N. Iki, N. Morohashi, F. Narumi, and S. Miyano, Bull. Chem. Soc. Jpn., 71, 1597 (1998); N. Iki, F. Narumi, T. Fujimoto, N. Morohashi, and S. Miyano, J. Chem. Soc. Perkan Trans 2.2745 (1998).

8. N. Iki, H. Kumagai, N. Morohashi, K. Ejima, M. Hasegawa, S. Miyanari, and S. Miyano, Tetrahedron Lett., 39,7559 (1998).

9. G. Mislin, E. Graf, M. W. Hosseini, A. D. Cian, and J. Fischer, Tetrahedron Lett, 40, 1129 (1999).

10. Selected spectral data of new macrocycles are as follows, Compound $3 ; \mathrm{mp}>300^{\circ} \mathrm{C}$. ${ }^{\mathrm{l}} \mathrm{H} \mathrm{NMR}(\mathrm{CDCl}) \delta 1.20(\mathrm{~s}, 18 \mathrm{H}$, 
$\left.\mathrm{C}\left(\mathrm{CH}_{3}\right)_{3}\right), 1.22\left(\mathrm{~s}, 18 \mathrm{H}, \mathrm{C}\left(\mathrm{CH}_{3}\right)_{3}\right), 3.43\left(\mathrm{~d}, \mathrm{~J}=8.5 \mathrm{~Hz}, 2 \mathrm{H},-\mathrm{CH}_{2}-\right), 3.46\left(\mathrm{~d}, \mathrm{~J}=8.5 \mathrm{~Hz}, 1 \mathrm{H},-\mathrm{CH}_{2}-\right), 4.26(\mathrm{~d}, \mathrm{~J}=8.5 \mathrm{~Hz}, 1 \mathrm{H},-$ $\mathrm{CH}_{2}$ ), 4.60 (d, J=8.5 Hz, 2H, $-\mathrm{CH}_{2}$-), 7.04 (d, J=2.0 Hz, 2H, Ar-H), $7.26(\mathrm{~d}, \mathrm{~J}=2.0 \mathrm{~Hz}, 2 \mathrm{H}, \mathrm{Ar}-\mathrm{H}), 7.11$ (d, J=2.0Hz, $2 \mathrm{H}$, $\mathrm{Ar}-\mathrm{H}), 7.28(\mathrm{~d}, \mathrm{~J}=2.0 \mathrm{~Hz}, 2 \mathrm{H}, \mathrm{Ar}-\mathrm{H}), 9.50(\mathrm{br}, 1 \mathrm{H},-\mathrm{OH}),(\mathrm{br}, 1 \mathrm{H},-\mathrm{OH}), 12.70(\mathrm{br}, 1 \mathrm{H},-\mathrm{OH})$, and $13.42(\mathrm{br}, 1 \mathrm{H},-\mathrm{OH}){ }^{13} \mathrm{C}$ NMR $\delta 31.21,31.52,33.22,33.64,33.95,33.96,123.36,125.28,125.74,126.15,127.54,128.21,132.04,132.75,141.53$, 143.24, 148.37, and 153.55; IR (in $\left.\mathrm{CHCl}_{3}, \mathrm{~cm}^{-1}\right) 3190(-\mathrm{OH})$; MS (FAB): $\mathrm{m} / \mathrm{z} 685\left(\mathrm{M}^{+}+1\right)$. Anal. Found: C, 75.52; $\mathrm{H}, 7.85$; $\mathrm{S}, 4.50 \%$. Calcd for $\mathrm{C}_{43} \mathrm{H}_{54} \mathrm{O}, \mathrm{S}: \mathrm{C}, 75.62 ; \mathrm{H}, 7.97 ; \mathrm{S}, 4.70 \%$. Compound $4 ; \mathrm{mp} 290{ }^{\circ} \mathrm{C}$ (decomp.). 'H NMR $\left(\mathrm{CDCl}_{3}\right) \delta$ $1.22\left(\mathrm{~s}, 18 \mathrm{H}, \mathrm{C}\left(\mathrm{CH}_{3}\right)_{3}\right), 1.23\left(\mathrm{~s}, 18 \mathrm{H}, \mathrm{C}\left(\mathrm{CH}_{3}\right)_{3}\right), 3.55\left(\mathrm{br} \mathrm{s}, 3 \mathrm{H},-\mathrm{CH}_{2}-\right), 4.29\left(\mathrm{br} \mathrm{s}, 3 \mathrm{H},-\mathrm{CH}_{2}-\right), 7.08(\mathrm{~d}, \mathrm{~J}=2.5 \mathrm{~Hz}, 2 \mathrm{H}, \mathrm{Ar}-\mathrm{H})$, 7.12 (d, J=2.5 Hz, 2H, Ar-H), 7.40 (d, J=2.5 Hz, 2H, Ar-H), 7.58 (d, J=2.5 Hz, 2H, Ar-H), 9.43 (br, $2 \mathrm{H},-\mathrm{OH}$ ), and 10.41 (br, $2 \mathrm{H},-\mathrm{OH}) ;{ }^{13} \mathrm{C}$ NMR $\delta 31.15,31.40,31.96,32.48,34.06,34.29,124.89,125.79,126.29,126.49,127.62,129.09,133.89$, 133.93, 143.79, 144.86, 146.56, and 150.43; IR (in $\mathrm{CHCl}_{3}, \mathrm{~cm}^{-1}$ ) $3300(-\mathrm{OH}) ; \mathrm{MS}$ (FAB): $\mathrm{m} / \mathrm{z} 699\left(\mathrm{M}^{+}+1\right)$. Anal. Found: $\mathrm{C}$, $73.61 ; \mathrm{H}, 7.70 ; \mathrm{S}, 4.53 \%$. Calcd for $\mathrm{C}_{43} \mathrm{H}_{54} \mathrm{O}_{6} \mathrm{~S}: \mathrm{C}, 73.89 ; \mathrm{H}, 7.79 ; \mathrm{S}, 4.59 \%$.

11. C. D. Gutsche, Calixarenes Revisited. In Monographs in Supramolecular Chemistry; F. J. Stoddart, Ed.; Royal Society of. Chemistry, Cambridge (1998).

12. C. Jaime, J. de Mendoza, P. Prado, P. M. Nieto, and C. Sanches, J. Org. Chem., 56, 3372 (1991).

13. V. Vesely, T. Stajanova, Collection Czeckoslov, Chem. Commun., 9, 465 (1937); M. M. S. Hoodgewerf, W. A. Van Derp, Rec. Trav. Chum., 21, 359 (1902).

14. R. J. Araham, J. Fischer, and P. Loftus, Introduction to NMR Spectroscopy, 2nd ed., John Wiley \& Sons, Chichster, (1988); Japanese translation by Y. Takeuchi, Kagaku-dojin, Tokyo, 223 (1993).

15. H. Tsue, M. Ohmori, and K. Hirao, J. Org. Chem., 63, 4866 (1998).

16. K. Ito, S. Izawa, T. Ohba, Y. Ohba, and T. Sone, Tetrahedron Lett., 37, 5959 (1996).

\section{Received on October 26, 2001}

